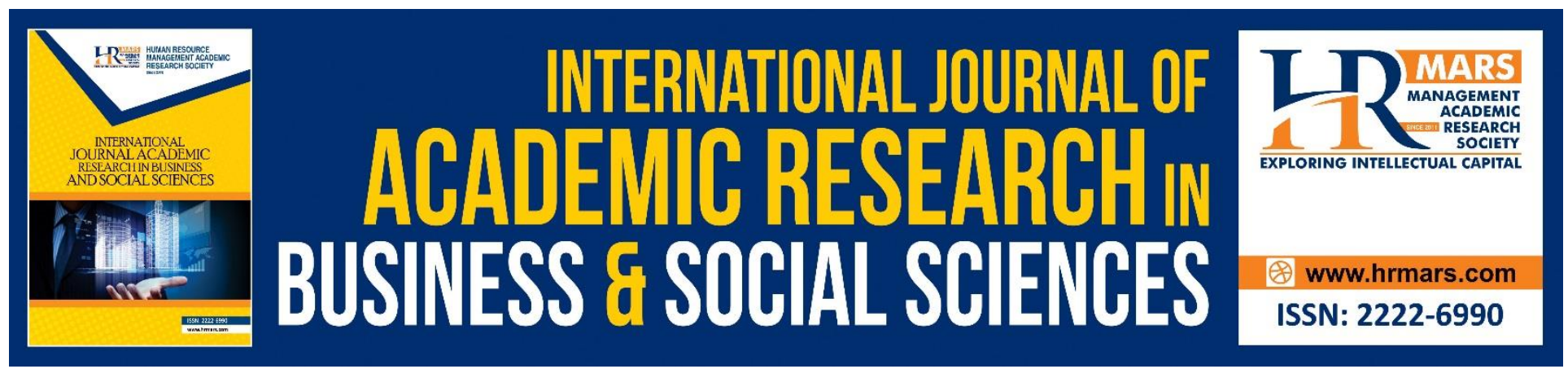

\title{
Academic Library Barriers: Case Study in Private University Library
}

Wilmina Lee, Saiful Farik Mat Yatin, Sufian Supahan, Ummi Halimatunssaadiyya Shamsul Yuzli, Syuhaidah Abdul Rahman, Abdul Rahman Ahmad, A'dillah Mustafa, Kasmarini Baharuddin

To Link this Article: http://dx.doi.org/10.6007/IJARBSS/v10-i11/8117 DOI:10.6007/IJARBSS/v10-i11/8117

Received: 07 September 2020, Revised: 29 September 2020, Accepted: 15 October 2020

Published Online: 08 November 2020

In-Text Citation: (Lee, et. al., 2020)

To Cite this Article: Lee, W., Yatin, S. F. M., Supahan, S., Yuzli, U. H. S., Abdul Rahman, S., Ahmad, A. R., Mustafa, A., \& Baharuddin, K. (2020). Academic Library Barriers: Case Study in Private University Library. International Journal of Academic Research in Business and Social Sciences. 10(11), 504-515.

Copyright: (c) 2020 The Author(s)

Published by Human Resource Management Academic Research Society (www.hrmars.com)

This article is published under the Creative Commons Attribution (CC BY 4.0) license. Anyone may reproduce, distribute, translate and create derivative works of this article (for both commercial and non-commercial purposes), subject to full attribution to the original publication and authors. The full terms of this license may be seen at: http://creativecommons.org/licences/by/4.0/legalcode

Vol. 10, No. 11, 2020, Pg. 504 - 515

Full Terms \& Conditions of access and use can be found at http://hrmars.com/index.php/pages/detail/publication-ethics 


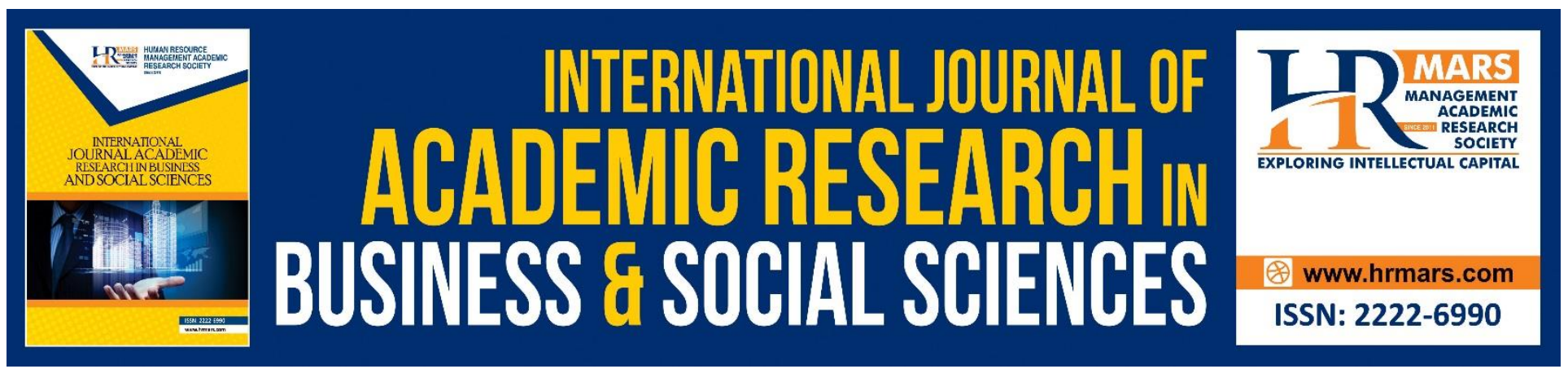

\title{
Academic Library Barriers: Case Study in Private University Library
}

\author{
${ }^{1}$ Wilmina Lee, ${ }^{1,2}$ Saiful Farik Mat Yatin ${ }^{1}$ Sufian Supahan, ${ }^{1}$ Ummi \\ Halimatunssaadiyya Shamsul Yuzli, ${ }^{1}$ Syuhaidah Abdul Rahman, \\ ${ }^{1}$ Abdul Rahman Ahmad, ${ }^{1}$ A'dillah Mustafa, ${ }^{1}$ Kasmarini Baharuddin \\ ${ }^{1}$ Faculty of Information Management, Universiti Teknologi MARA (UiTM) Selangor, Malaysia \\ ${ }^{2}$ Members of Advanced Analytics Engineering Centre (AAEC), UiTM Malaysia \\ Email: farik@uitm.edu.my
}

\begin{abstract}
Academic libraries play an integral part of all higher learning institution. It serves as a support for users of the library which inclusive of students, academics as well as other supporting and administrative personnel of the institution. It provides important resources that supports research, teaching and learning experience of students and academics. This paper investigates how a local private university library identified and overcome barriers that has emerged within the academic library. This article presents six key problems that the library encountered and the solutions that was recommended to overcome the barriers. Major findings within the library includes various forms of obstacles in order to maintain library relevance to the institution, difficulties that are mainly faced by the library consist of visibility of its core function, inadequacy of the library's services and facility, lack of internal communication with the faculty and the most critical issue faced is financial budget cuts by the management of the institution. It is important that library personnel develop excellent critical and creative thinking skills as well as important soft skills especially good interpersonal communication and relationship with the faculty in order to overcome the barriers faced in the $21^{\text {st }}$ century librarianship and maintain the library's relevance to the institution.
\end{abstract}

Keywords: Academic Library, Barriers, Problems, Solutions, Recommendations.

\section{Introduction \& Background}

This article focusing on the case study of the library in top private universities in Malaysia that serves over 11,000 students and approximately 1,500 staffs in the year of 2019. The university was first established in 1969 as university college then granted as University by 2010. In the following year, it has been earned the QS Asia University Rankings - The Number One Private University in Malaysia (non-GLC) and Reader's Digest Trusted Brand award - The Gold Award Winner in Private University/College Category. In 2019, the University has celebrated its $50^{\text {th }}$ anniversary. There are 
INTERNATIONAL JOURNAL OF ACADEMIC RESEARCH IN BUSINESS AND SOCIAL SCIENCES Vol. 10, No. 11, 2020, E-ISSN: 2222-6990 @ 2020 HRMARS

four (4) faculties under the academic provision whereby each faculty consists of few Schools and Department designed to align their teaching and learning closely with industry practice and headed by an Executive Dean that responsible for steering the respective faculty 's success and strategic direction.

Initially, four (4) campuses were under the universities and college management, but, due to the restructure of organization in January 2017, colleges have been relocated and merged with the main campus. Considering the need of Year Two (2) medical students to be closer with the hospital as part of their learning process (practical and job training), therefore, the clinical school has been remained. These changes directly affected the operations, workforce as well as the management of the campuses and its collections. This is due to all college's libraries staff has been affected by the Mutual Separation Scheme (MSS) and no manpower were available to mend the college libraries, even no replacement to the resigned staff. The task has been shared among university libraries staff to cover the college library operation with no additional allowance given to them.

In university governance, Library has been placed under Chief Operating Officer (COO) starting from 2017 and reporting to Chief Information Officer (CIO) who is also directing Information Communication Technology (ICT) department. In 2019, the Head Librarian joined the Library as a replacement for the Chief Librarian and supervised the 24 library staffs from two (2) divisions that are Client Service Division and Information Resources Division inclusive of three (3) Assistant Managers, one (1) Senior Librarian, ten (10) Librarians with the support staff consist of Library Officers (2), Senior Library Assistant (1) and Library Assistants (7). These staff were assigned to the four main units within the two (2) divisions that are Lending Services Unit, Information Services Unit, Information Technology Unit and Acquisition \& Cataloguing Unit.

\section{Library Barriers/Problems and The Recommended Solution}

In this case study, there are six (6) major challenges has been identified which possibly affecting the library service performance and impression towards it. The possible solutions and action plan were suggested to overcome the issue observed in the Library to gain the appreciation from the community towards library's roles and functions.

\section{Awareness on Library Services}

It is found that neither student nor staff did not aware on the services and facilities offered to them, hence they did not know their privileges despites the massive promotional activities done by the Library to maximize the usage of the existing services and facilities. From the very basic information they should aware and know of like the borrowing privileges, document delivery services to the specifics and extended services such as research assistance, information literacies classes and guidance as well as request for the purchase seems doesn't hit them. This is proven when the library did an analysis on the inquiries and feedback received via the desk, library official email, surveys and the meetings between library and school, it is found that the same issue were repetitively raised by its users since 2013. 
INTERNATIONAL JOURNAL OF ACADEMIC RESEARCH IN BUSINESS AND SOCIAL SCIENCES Vol. 10, No. 11, 2020, E-ISSN: 2222-6990 @ 2020 HRMARS

Table 1: Enquiries and complaints received since 2013

\begin{tabular}{|c|l|c|}
\hline No & \multicolumn{1}{|c|}{ Enquiries/Complaints } & Total Enquiries \\
\hline 1 & How to settle the overdue loan & 131 \\
\hline 2 & Username and password to access account & 105 \\
\hline 3 & $\begin{array}{l}\text { Queries on databases subscription, EZ-proxy login, access to } \\
\text { e-Repository }\end{array}$ & 97 \\
\hline
\end{tabular}

Library has made improvement to the reminder letter content sent to the users as a courtesy to the borrower to settle their pending library item, unfortunately, it is recorded that 131 inquiries was received pertaining to this matter. Similar to inquiries on the login information to My Account despite the information were made available in the website, 105 enquiries was received, followed by 97 enquiries on accessing the online resources for example simple enquiries on the availability or subscription of the databases, login into the Ez-Proxy and also retrieve the material in e-Repository. This statistic shows that the information distributed to the student through the website as a major source of information, notices and announcement, posters, social media and another channel did not reach them. Or it could be due to the ignorance and user does not feel the information is important to be read.

Possible reasons that could lead to this situation and ineffective in engaging the user through the advertised information is the design and content of the information for example, too wordy and too much information potentially caused the confusions and misleading, besides it will not interest them to read the entire message or information. To tackle the user nowadays, especially the young generation, it is advisable to use the infographic presentation with catchy, simple, and sweet wording which is more attractive to them. In the study did by Aderibigbe and Farouk (2017) they pressed that to ensure the optimum usage of resources and services, immediate attention to resolve the issue is extremely required by focusing on the major concern in the case of the user express to ignore the roles and function of the library that indirectly impact them missing vital information which is obviously important to help and guide them of being a better intellectuals. Furthermore, they will become unfamiliar with the library rules and regulations, the policies and unable to adhere to the process and raise more dissatisfaction and disappointment.

As described by Yi (2016), to compete with other, library services which is the precious asset of the library should be marketed and promoted to the user. In this case, Librarian will need to work hard to make aware of the existence of the library to its community and find the possible approach to reach the user. In addition to the existing Frequently Asked Question (FAQ) presented on the website, the Library has researched and considered using the Chatbot Program to facilitate the dialogue of the top 100 questions that have been collected since 2015 on different feedback platforms. The preferred way to ask the library question might be to provide interactive contact between the user and the devices. Therefore, Chatbot has been observed as one of the alternative methods for communicating with users who may not be familiar with the facilities and the library generally.

In order to reach the students via all possible channels available and used within the university in promoting and communicating the information from the library, appointed library staff has been granted to utilize the system designed by the Information Communication Technology (ICT) as well as Campus Central (CC). Since everyone has the smart phone, university mobile apps have been seen as the right platform to share the Library notices, announcement, new and events organize by the 
library. The message will be sent directly to their registered email and students will be able to view and read it just by login into the mobile apps. The friendly features to send the messages via mobile apps smoothen the process as the targeted audience will be automatically choose from the listed programs. Meanwhile, the message sends through Campus Central portal offer more variety of information presentation that has ability to accept the content with images or videos. The content will be automatically appeared in Student Portal page under the Announcement column of the front page. In responding to the massive usage of the social media by most of the people around the world, the Library did not leave behind and took the same opportunities to engage its user via Instagram, Facebook, and Instagram. Among the post by the Library to attract its user covering the interesting event happening inside the Library - current and future, announcement and notices on the maintenance work that affecting library areas, services and facilities, the announcement on the revision of operation hour or closure of the library, besides the selected quote of the day to boost the motivation and also the image of the day as part of library initiatives to give a good impression that the library is not a boring place and the posting does not all about library things. To make it happen, a creative staff must be identified so that the outcome of the content is interactive and attractive yet effective to distribute the information to the user.

\section{Attachment and Engagement}

Roles of librarian has become more challenges as it been through frequent changes due to the restructure of the organization, and require the librarians to focus in depth into the core activities, hence, they are unable to spend much time with the faculty members and they can't fulfill their function as liaison librarian at optimum level. This situation has formed a barrier between the library and the faculties whereby the consequences is the academicians did not know their privileges and services that they may get the advantages from offered in the library.

The gap concerning of the interdepartmental relationship and communication between two parties resulting to the difficulties faced by the Library in disseminating valuable information to the faculties member. The efficacy of collection development for that faculty or school is one of the significant activities that is adversely affected by this outcome. As opined by Hunt (2017), collection development is one of the critical components of the librarianship to ensure an adequate and appropriate resources are made available to support the teaching, learning and research process either for the students or the academicians. In the study, the author provided a scenario to describe the situation whereby the faculties likely fail to see the announcement or email sent by the library on the timeline to complete the collection developments. This has forced the library to adjust their time frame in acquiring and purchasing for the item. It is more challenging to the library when the lecturers decided to submit the list of the new titles to be purchased at the end of the year, whereby the library can't proceed to process the request as it reach the purchase cutoff date as set by the management to close the account. This ineffective collaboration in the collection development process will directly impact the accreditation as one of the major requirement stated by the Malaysian Qualifications Agency (MQA) is that the titles derived from the main text reading list of the subject module must be made available inside the library regardless of electronic or printed format.

In addition to the above, the Library has determined that the situation created by this current discrepancy has resulted in a number of faculty members not recognizing that the updated resources, services and facilities of the library are available for them. It is essential to build an effective service 
INTERNATIONAL JOURNAL OF ACADEMIC RESEARCH IN BUSINESS AND SOCIAL SCIENCES Vol. 10, No. 11, 2020, E-ISSN: 2222-6990 @ 2020 HRMARS

awareness to serves the user with the most updated information (Mountifield, 1995). The library will, in turn, be able to sustain a high usage rate that amounts to a positive investment return (ROI). Lockley (n.d) listed ten (10) internal communication problems that are lack of response or input, email overload, general lack of communication, device chaos, new staff, language barriers, communication of internal and external news, excessive of irrelevant or useless information, lack of respect, lastly, budget constraints.

The buffer for email communication is very long as it is a structured way of communicating with the white noise it gives whenever the user would be included in an email. It may cause the late in responding to the email or phone call using the office network. As the academician are not entirely available in the office, this approach was found ineffective. It is crucial that librarians begin to select a way of connecting using informal channels including the WhatsApp, a text application that some employees consider to be a more personal communication channel, having said that the key term mentioned here is a semi-formal mode of communication in which it is a more informal way of communicating, yet restricted to the limits of working hours and the environment. The library must find a way to be able to response to the queries promptly when it comes to the communication through the traditional methods. Cunningham and Lanning (2002) suggested that the new information boundary has parallels to gold rushes and migration to the past, whereby anybody can openly assert any expertise that may emerge from the fact that there are loads of information out there. To differentiate themselves from the pack, students and lecturers need to learn how to retrieve efficiently, analyze objectively, and integrate information into their knowledge frameworks. Information literacy is not a destination, it is a continuous path that is considered as the gateway to lifelong learning. The need for this service expands to literacy skills as a high percentage of either lecturers or students has difficulty navigating through Library materials as well as assessing the legitimacy of the source they wish to use for assignment or study. The information literacy classes are needed especially to the users who are battling to find and use the library resources. The knowledge somehow must be taught not only through the traditional classroom methods, it is crucial for the knowledge to be distributed to the user via various electronic forms as the information professionals are transforming in an ever-multi-tasking environment, as the hours of a day are very valuable in the rapid speed of development that we are at the arrival of the 5th. Industrial Revolution. Librarians are working diligently to discover the new means and approaches to facilitate their relationship with faculty on a college campus with the goal of providing meaningful and efficient experience to support student work. As stated by (Massis, 2012), although various software collaboration tools are available on the market to facilitate in any of these tasks, the human element remains the key to achieving tremendous success through organized cooperation and partnership between faculties and the librarians. There are multiple solutions to be considered when this problem is addressed. Relating to the problems Library has agreed to make use of a range of applications and channels that can address the difficulties of working with the faculty to accomplish the objectives and purpose of the universities. In an attempt to minimize the gap between both parties, the Library has taking an initiative by implemented series of workshop or program that offers a medium for the academicians to learn and explore on the Library resources, services and facilities. The initiatives are part of the Library action to tackle the issue of miscommunication with the faculties, therefore it is essential for the library to establish the appropriate policies and process flow to support the accreditation. 
INTERNATIONAL JOURNAL OF ACADEMIC RESEARCH IN BUSINESS AND SOCIAL SCIENCES Vol. 10, No. 11, 2020, E-ISSN: 2222-6990 @ 2020 HRMARS

The challenges of using the email to communicate on the collection development is that the recipient may not respond to the email within the stipulated time or overlook the email in order to confirm the purchasing. As a solution, Library with advice and collaboration with ICT to utilize the Share Point platform with the customization according to Library requirement, hence, the new product has been successfully created known as Reading List Management System (RLMS). The platform is accessible and editable by the Program Directors and Module Leaders to update their reading titles according to the latest curriculum modules. To improve the communications among the community, the TEAMS, a Microsoft software has been introduced by the ICT and widely used by the employee in their working environment. TEAMS enable workers to communicate through improved collaboration by allowing users to conduct a video conference calls and multiple staff to edit the same document simultaneously.

\section{Layout and Design Encourage Noise}

The major issues identified since the library started its operation in 2010 is the noise. This is due to the modern design of the library that encourage collaborations and adapting relaxing concepts with garden in each floor. To match the concepts set by the interior designer, the seating type is more to group study table, soft seating like the sofa, couch, bench type of seating instead of individual seating. Hence, the furniture type has influenced and encourage the student to have a discussion or talking to each other in a group. The noise will be combined and bounced when everyone in the group talking even though they did not talk loudly. There are $27 \%$ (459 complaints) has been received through the survey and attended at the counter since 2013 on the dissatisfaction towards noise issues and it has been frequently raised up into several meetings such as Staff Welfare Meeting (SWM), Library Committee Meeting (LCM), Student Welfare Committee Meeting (WSCM) and Student Staff Consultative Meeting (SSCM).

The discussion room does not position in a strategic location and scattered from level 2 to 5 . Without the soundproof panel to absorb the sounds cause the noise travel from inside to outside of the room. Besides that, the biggest source of the noise was observed from the void area, located at lounge area, level 2, the lowest level of the library as it causes the noise reach up to Level 5 . It is unquestionable that the library has been benchmarked many times by other institution due to the modern design and the contemporary design of the furniture used. However, it is not suitable for the silent environment and do not conducive for the users. The promotional and awareness activities to promote the zoning area were actively done by the library staff through the websites, posters besides signage has been made visible to the users at each area. Sadly, the noise problem recurring year by year. This is supported by Lange, Nesbitt, and Severson (2016) as in their research that the most commonly complaints the library department will received is the noise issue. The authors found that to overcome the problems, library has taken dan developed many actions, measurement, strategies, and initiative. Besides the noise issues, even though the project involving cutting, reassembling the sculpture / prototype and gluing is strictly prohibited in the Library, students ignorance causes the damage to the tables surfaces and leaving the debris from the projects around the places. According to McDiarmid and Tatum (1938), there are two types of noises that are 1) background noises and 2) service noise.

First type of noise that is background noise refers to the noise came from the outside or repetitive sounds derived from the air-conditioning system. Meanwhile, furniture movement, book trolleys or 
footsteps sound categorized as service noise. The noise could not be possibly fully eliminated, it may be reduced at acceptance level. One of the consider solutions to the library is by installing the acoustic panel even though it will cost a lot of money. The ability of the acoustics solution is if the noise frequency recorded is at 500 , it will be capable to absorb the noise up to $90 \%$. Theatrette identified as one of the rooms that need this solution as the sounds from the screening can be heard from the closest area for example MacLab, Computer Lab and the Printing Area. Installation of the noise meter in the critical area such as Silent Area is another alternative solution. In the case of the noise has reached the acceptance noise level, library staff will be notified by the alarmed and alert sent through the light indicator or emails.

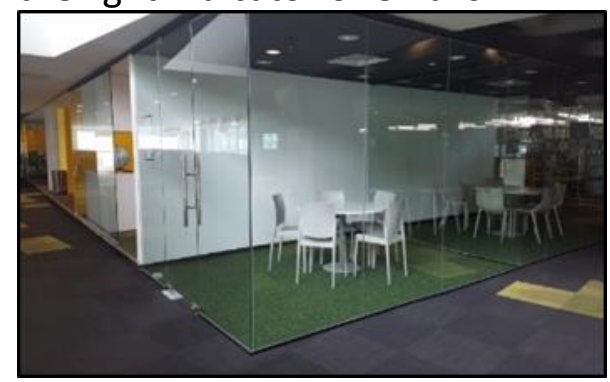

Figure 1: Discussion room

According to Davis (1987) "A little innovative thinking will go a long way towards alleviating the issue without generating a whole new set of problems to deal with." Re-layout and re-design the library spaces to match the zoning area requirement (Silent Area, Quiet Study Area and Collaboration Area) is crucial besides the plan to install the noise reduction solution. In Silent Area and Quiet Study Area, the furniture such as soft seating, sofas and group study tables which is found invited people to talk removed from the Silent Area and Quiet Study Area. Instead, these furniture suits the area that permit users to collaborate and engaged in a group such as collaborations room, lounge are and the collaboration bridge. As a replacement for the group study tables, newly purchase individual seating and carrel with sound absorption panel and plug points was placed in Level 4 \& 5 .

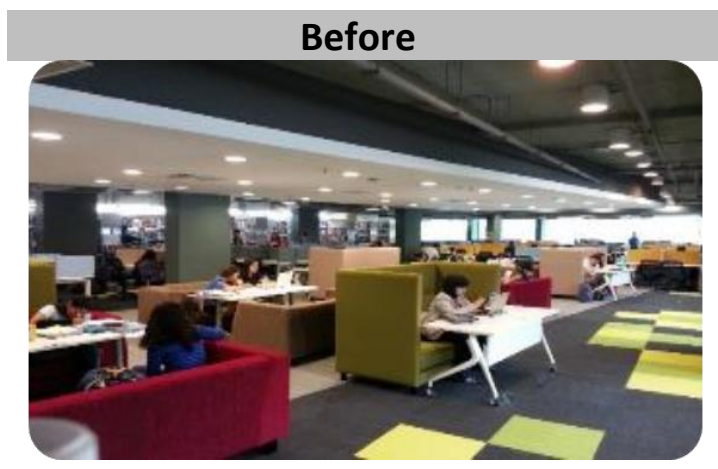

Figure 2: Group study seating

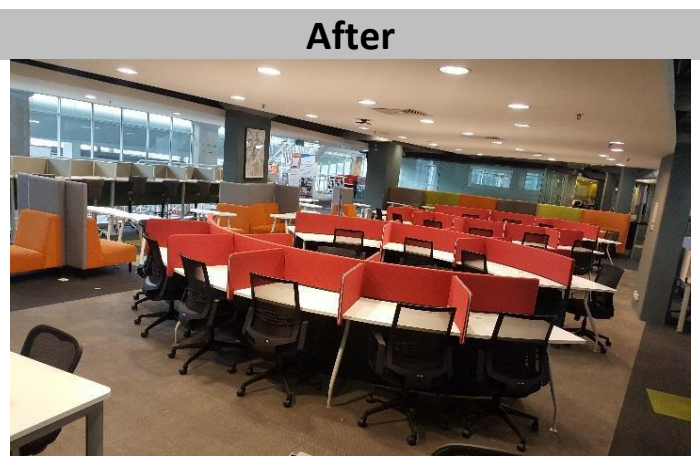

Figure 3 Individual seating equipped comes with acoustic panel and plug point each table 
INTERNATIONAL JOURNAL OF ACADEMIC RESEARCH IN BUSINESS AND SOCIAL SCIENCES Vol. 10, No. 11, 2020, E-ISSN: 2222-6990 @ 2020 HRMARS

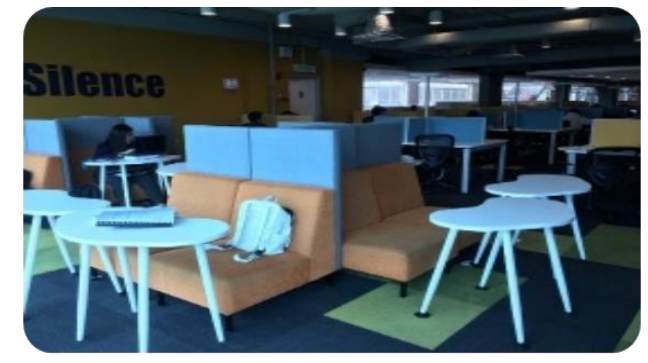

Figure 4: Group study seating

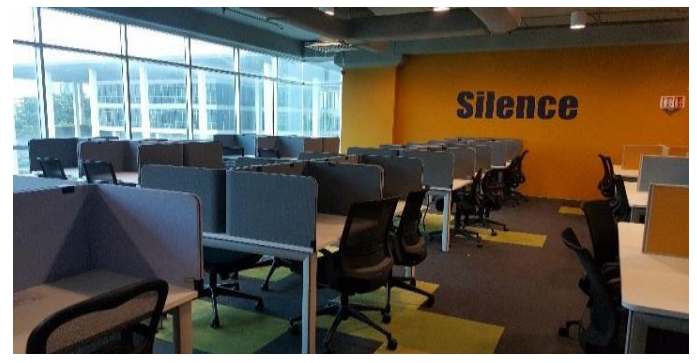

Figure 5: Re-design the space

The library has planned to refurbish and transform the Quiet Study Area to become a Silent Study Area as action of improvement and fulfill the students request to have more silent areas for private study. The plan is to remove the 30 sofas and 30 groups study tables with the same type of furniture available in Level 4. Gladly, after the refurbishment and renovation completed in 2015 , it was a huge success when only 9 complaints have been formally raised by the users. Its shows that the strategies of re-designing the library spaces is effective to reduce the noise issue in the Library. The issue of the noise came from the footstep when students walk on the staircase maybe resolved if the staircase can be covered with the carpet as it does have a sound absorption features, with addition of the staircase nosing install at the edge of the staircase to avoid the slippery.

\section{Space}

The library's user growing tremendously as the enrollment of the new student with the universities has been increased year by year. This development forces the library to find ways to achieve the minimum requirement as set by Ministry of Educations for the private universities that the seating capacity must be able to accommodate the university population that is $30 \%$ of student and $20 \%$ of staff. With the current number of students and staff in the university, the Library need to ensure 3,360 seats is available for its users. However, currently, Library is only able to fit in 2,700 seating capacity, means there are additional 660 seats should be made available to meet the standard. Hence, the Library is enthusiastically study and find the possible space that could be transformed into a seating area. The Library has been frequently dealing with the dissatisfaction experience from the student towards the insufficient seating when the issue has been discussed and expressed in various meetings, survey, and input from the students. Since the library survey distributed to the students starting 2013, accumulatively, there are 227 complaints (14\%) on the seating issue has been received from them. It is reflecting that students wanted more individual seating type for better study and learning experience. In the Library, to cater more than 120,000 printed collection, 35 rows of double sides shelves were installed which occupied over 300 square meters of the overall space. The Chief Operating Officer (COO) seen this area could potentially transform into a seating area, therefore he recommended that the number of shelve could be reduced and removed - seven (7) rows of double sided shelve in Level Three (3) and two (2) in Four (4). By removing the nine (9) shelves, the 73 new seats will be added. Despite the massive weeding was performed by removing approximately 12,000 books from the collections, it does not able to remove any shelve. This is due to the new arrival book will occupy the empty spaces. After the analysis done by the team with some benchmarking has been made, it is decided that it is not possible to decrease number of shelve. 
As the shelve cannot be reduced, other spaces have been studied and identified. In 2018, the staff office that is Lending Services working space, the counter and the Reserve Collection area has been renovated into four (4) discussions that can accommodate 44 seats. With the changes, the office then relocated to the smaller space located at Level 2 besides the sorting room, while the Lending Services desk has been combined with Enquiry Desk. Another space discovered that can accommodate 35 seats was the space alongside of the railing in Level 3 and Level 4 . As the planter box with potted plant in Level 5 has taking space and potentially invited mosquito, it has been demolished and 12 seats was successfully made available in the floor. Due to the space constraint in the shelve area, the Library has changed their policies of collection development whereby the Library will focusing on ebook purchase, while the print is only obtain if the e-book is not available for that title. Originally, library will purchase four (4) copies per title in the reading list, however, only two (2) is granted for requisition. Currently, over 694,049 of e-book with multi-disciplinary subjects which is suitable for university and college student has been subscribed.

\section{Library Funding}

To minimize the operational costs of universities and colleges, numerous series of Volunteer Separation Schemes (VSS) and Collective Separation Schemes (MSS) have been implemented. It was followed by the budget reduction affecting all department including Library. From the RM4 millions budget that used to be given to the Library that covers expenses for the collection development, subscription renewal and services and facilities maintenance fee, Library has forced to cut their operation budget and works with a very minimal cost, however the good services must be maintained as it is. It does affect the improvement plan for better customer experience including procurement of title from the Reading List, collection development for each program, the acquisition of software or hardware to support the activity of the library, and enhancement of the furniture and fittings in providing a comfortable seating that suitable for longer periods of time. Starting 2015, Library has been pressured to eliminate and completely stop the renewal of serials item and pricey online databases. To defend the renewal and subscription, Library has made thorough study and analysis, however, the management seen it cost lot of money to be spent and does not return much profit to the company. Along with this, management has forced the Library to identify other Library Management System (LMS) that offer cheaper maintenance fees. In respond to this decision, to reduce the costs as low as possible, Library has researched the other library management system available on the market, including all the open source system. KOHA was listed as the proposed system to be pursued by the library, after comparing the management costs and the capacity to finance the operation of the library. In addition to seeking a solution to the library management system, Library is also urged to work closely with the ICT department to create creativity through the development of its own system. To ensure that the services and resources is ready before the commencement of the new semester, Library need to work very closely with the school as updating the reading list is urgently needed to fulfill the accreditation and promoting the teaching and learning activity. Therefore, it is important for the Library to engage and collaborate with ICT department in creating the Reading List Management System to be used between librarian and the lecturers. There is no manual updating and extracting involve by using the system to avoid delay in processing the reading list and the communication between them can be done via the system itself. Should there is enhancement required, Library will liaise directly with the ICT. At the same time, the Library will 
INTERNATIONAL JOURNAL OF ACADEMIC RESEARCH IN BUSINESS AND SOCIAL SCIENCES

Vol. 10, No. 11, 2020, E-ISSN: 2222-6990 @ 2020 HRMARS

review and identify free and open source of software and applications that potentially be used to design the announcement, presentations, video editing of library content.

\section{Security Breach and Theft}

By end of 2017, all college library staff has been tendered with the Mutual Separation Scheme (MSS) that cause no manpower left to mend the college library which has been moved to the main campus. The 'self-service library' concept has been applied to college library, therefore, suitable equipment with technology was provided such as Book Return for returning, self-check machine for borrowing, detection gate to be triggered in case of book did not properly borrowed, access card reader to enter and exit the library, Print on Demand (POD), Skype and phone line at the Information Desk. Each equipment and machines that students will be using has been provided with the manual and guides since there is no staff around to assist them immediately. In 2018, when the stock taking activities taking place for inventory purposes, there are 71 items $(0.61 \%)$ were found missing from the shelve with no transaction recorded in the systems. This has caused the loss of RM15,000 of the library asset. With the presence of the detection gate in the library does not guarantee the user taking the book without make any borrowing to their account as when the gate triggered, no library staff there to stop them. Gratefully, student with good attitude, honest and have a sense of belonging, make an effort to contact the staff in university library to inform on the incident and to get the assistance. Other risk is the user will bring along their friends (non-registered student/staff) to the library. In some cases, anyone could enter the room if the door left open to anyone without the ID. This will lead to the safety issue of the students inside the library and missing collection. Due to the power surged happened in the Library, it caused the damaged to the seven (7) equipment which Library has bear the cost of RM36,000 to repair the equipment to ensure the college library able to operate as 'self-service' library.

After the incidents, there librarians from university library has been scheduled to work in the college library from $11 \mathrm{am}-2 \mathrm{pm}$, whereby they are performing the task such as assisting with borrowing and returning, patrolling and headcount, shelving and shelf read, and also provide the assistance of reference and information services. There are eleven (11) CCTV has been installed in the library and can be monitored by the Lending Services staff from their office to monitor user's activity, which is also been shared with Security Department office. The statistics and the report from the Security Department is required for the Lending Services team to analyze and propose future plan for example to add more security tools or perhaps recruit a staff to mend the library. Skype is the medium of communication prepared to the students to connect with the Librarian if they need assistance in accessing the resources, beside the helpline for requesting and immediate assistance. Every two (2) hour, the Lending Librarian will be visiting the library to ensure the equipment and facilities working well and ensure the library is under control. In addition, the library partnered with the equipment manufacturer to install software that would be able to send a warning if there was an error on the devices - Book Return, Self-Check and POD in case it the machines is out-of-service, error in printing the receipt, not connected to the library system or out of paper. 
INTERNATIONAL JOURNAL OF ACADEMIC RESEARCH IN BUSINESS AND SOCIAL SCIENCES Vol. 10, No. 11, 2020, E-ISSN: 2222-6990 @ 2020 HRMARS

\section{Conclusion}

The similar issues and challenges discussed above maybe faced by other libraries around the world. Mohammad Aslam (2018) pointed out that in order to solve the libraries problems and challenges, skills such as critical thinking and creative thinking skills could contribute to the best decision-making in the 21st century, with the addition of good leadership that may have had an effect on the library roles and functions. Leadership skills such as communication and interactions, social engagement, understanding on the organizational vision and mission need to be developed in order to tackle these challenges. Therefore, Librarian are encouraged to align themselves with the initiation of the innovations to maintain libraries reputation and validity to the society.

\section{References}

Aderibigbe, O. A., \& Farouk, B. L. (2017). Challenges on Marketing of Information Resources and Services in Federal University Libraries in North-West Zone of Nigeria. International Journal of Academic Library and Information Science, 5(3), 92-96. https://doi.org/10.14662/IJALIS2017.015

Aslam, M. (2018). Current trends and issues affecting academic libraries and leadership skills. Library Management, 39(1/2), 78-92. https://doi.org/10.1108/LM-10-2016-0076

Buckland, M. K. (1989). Article information: Journal of Documentation, 45(3), 213-226. https://doi.org/10.1108/eb026844

Cunningham, T. H., \& Lanning, S. (2002). New frontier trail guides: Faculty-librarian collaboration on information literacy. Reference Services Review, 30(4), 343-348. https://doi.org/10.1108/00907320210451349

Davis, M. C. (1987). Reutilizing Existing Library Space. Retrieved from ttps://core.ac.uk/download/pdf/4816877.pdf

Hoffman, S. (2011). Embedded academic librarian experiences in online courses. Library Management, 32(6/7), 444-456. https://doi.org/10.1108/01435121111158583

Hunt, S. (2017). Collection development in UK university libraries. Collection Building, 36(1), $29-343$. https://doi.org/10.1108/CB-09-2016-0026

Lange, J., Miller-Nesbitt, A., Severson, S. (2016) Reducing noise in the academic library: The effectiveness of installing noise meters. Library Hi Tech, 34(1), 45-63. DOI: https://doi.org/10.1108/LHT-04-2015-0034

Massis, B. E. (2012). Librarians and faculty collaboration - partners in student success. New Library World, 113(1), 90-93. https://doi.org/10.1108/03074801211199077

Mountifield, H. M. (1995). Electronic current awareness service: a survive tool for the information age. Journal of Library Administration, 13(4), 317-324. https://doi.org/10.1108/eb045382

Zhi, X. Y. (2016). Effective techniques for the promotion of library services and resources, 21(1), Paper 702. Retrieved from http://www.informationr.net/ir/211/paper702.html\#.XNohkeUzbIV 